\title{
Formation of Molecular Membranes in Water from Ionene Oligomers and Related Amphiphiles ${ }^{\dagger}$
}

\author{
Toyoki Kunitake, * Akihiko Tsuge, and Kunihide TAKarabe \\ Department of Organic Synthesis, Faculty of Engineering, \\ Kyushu University, Fukuoka 812, Japan
}

(Received September 19, 1984)

\begin{abstract}
Ionenes were prepared by reaction of $\alpha, \omega$-dibromoalkanes and $\alpha, \omega$-bis(dimethylamino)alkanes at room temperature. The degree of polymerization as estimated from NMR data was 2 to 5 . The oligomeric ammonium amphiphiles (ionenes) thus obtained gave molecular weights of $10^{5}$ to $10^{8}$ in water. Vesicles of the molecular membrane were formed by self-assembly of the $\mathrm{C}_{20}$ ionene. A related bis-ammonium amphiphile gave similar results. The introduction of symmetrical aromatic rings into the middle of the $\mathrm{C}_{20}$ chain did not change the general aggregation behavior. Differential scanning calorimetry indicated the presence of gel-to-liquid crystal phase transition in these cases. No membrane formation was observed when the methylene chain length was shorter $\left(C_{10}\right.$ and $\left.C_{12}\right)$ or the two methylene portions were uneven in length $\left(C_{20}\right.$ and $\left.C_{16}\right)$.

KEY WORDS Molecular Membrane / Ionene Oligomer / Electron Microscopy / Differential Scanning Calorimetry / Self Assembly /
\end{abstract}

Both we ${ }^{1}$ and other research groups have found that a large variety of synthetic amphiphiles undergo spontaneous assemblage to bilayer membranes. ${ }^{-}$An interesting development in this field is the incorporation of a polymeric nature into these membranes. Ringsdorf and others ${ }^{3}$ classified the modes of the polymerization of bilayer membranes, and Fendler and Tundo ${ }^{4}$ summarized recent data on the preparation and utilization of polymerized bilayers. The modification of polymer surfaces by polymerized membranes is a controversial topic. ${ }^{5}$

We investigated the formation of molecular membranes (monolayer and bilayer) from polymeric amphiphiles such as water-soluble vinyl copolymers. ${ }^{6.7}$

In this article, we describe the spontaneous formation of monolayer membranes in water from ionene oligomers and related amphiphiles. In the past, a variety of ionene poly- mers containing aliphatic and aromatic segments were prepared, and their solution properties as polyelectrolyte studied. ${ }^{8.9}$ In this cases, the methylene chain or the aromatic segment connecting the ammonium groups are short (less than the equivalent of $\mathrm{C}_{10}$ ).

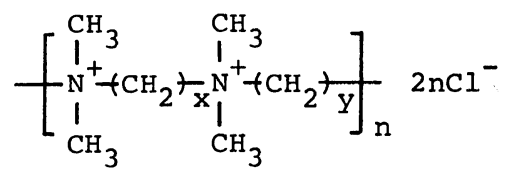<smiles>CC(C)(CCl)Cc1ccc(C[N+](C)(C)C[N+](C)(C)CC[N+](C)(C)C)cc1</smiles>

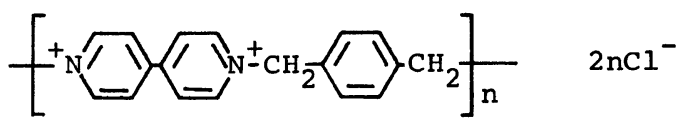

Chart 1. Typical ionene polymers.

+ Contribution No. 752 from Department of Organic Synthesis.

* Address correspondence to this author. 


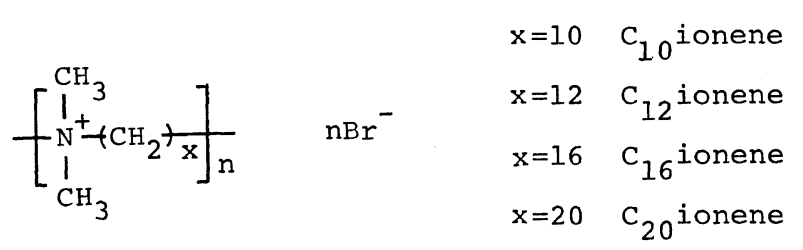
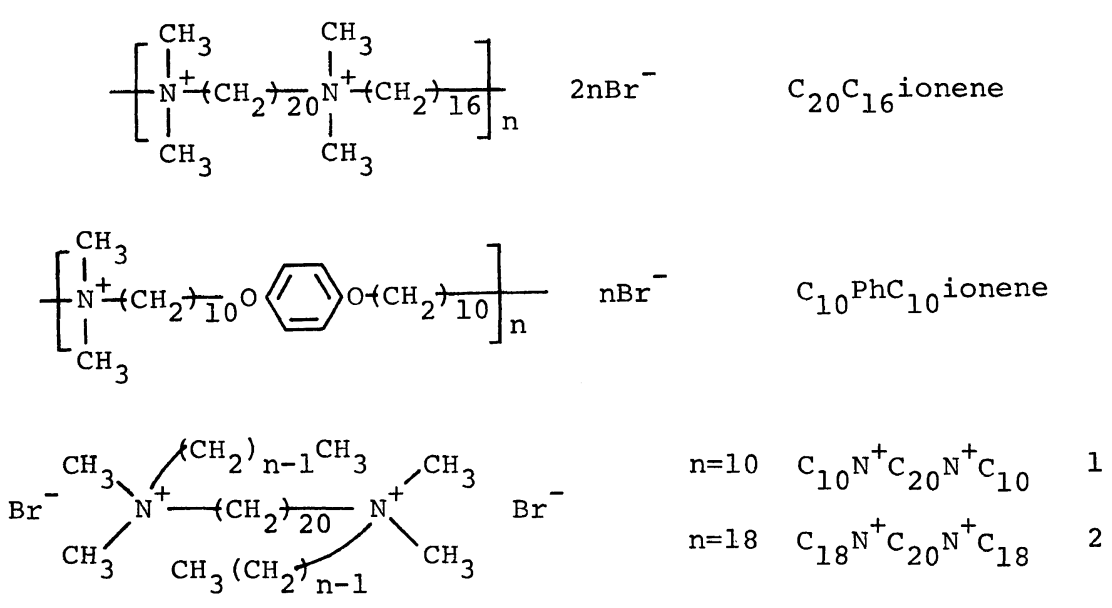

Chart 2. Bis-ammonium and ionene.

Stable bilayer membranes are formed from dialkylammonium amphiphiles with alkyl tails of at least $\mathrm{C}_{10}$. The total alkyl chain length corresponding to the bilayer thickness should thus be at least $\mathrm{C}_{20}$. We previously reported that stable monolayer membranes are produced from two-headed single-chain amphiphiles. ${ }^{11}$ It should be of interest to see whether the covalent connection of two double-chain molecules at one of the alkyl chain end could give membrane-forming compounds. For this purpose, we prepared bisammonium amphiphiles $\left(\mathrm{C}_{10} \mathrm{~N}^{+} \mathrm{C}_{20} \mathrm{~N}^{+} \mathrm{C}_{10}, 1\right.$ and $\mathrm{C}_{18} \mathrm{~N}^{+} \mathrm{C}_{20} \mathrm{~N}^{+}$$\mathrm{C}_{18}, 2$ ) and a series of ionene polymers and examined their aggregation behavior.

\section{EXPERIMENTAL}

\section{Materials}

$\alpha, \omega$-Dihydroxyalkanes, as purchased or prepared from the corresponding dicarboxylic acids via esterification and $\mathrm{LiAlH}_{4}$ reduction, were converted to $\alpha, \omega$-dibromoalkanes by $\mathrm{HBr}$ gas $^{12}$ or by concentrated hydrobromic acid in ligroin $^{13}$; 1,12-dibromododecane, bp 125$127^{\circ} \mathrm{C} / 0.04 \mathrm{mmHg}$; 1,16-dibromohexadecane, mp 50-52 C; 1,20-dibromoeicosane, mp 66$68.5^{\circ} \mathrm{C}$. $\operatorname{lit}^{14} \mathrm{mp} 67.4-68.0^{\circ} \mathrm{C}$. Subsequently, 1,20 -dibromoeicosane was dissolved in benzene and allowed to react with a large excess of dimethylamine in a sealed ampoule at $90^{\circ} \mathrm{C}$ for $118 \mathrm{~h}$. The reaction mixture was neutralized with dilute alkali and the product was recovered from the organic layer and recrystallized from acetone: yield $80-90 \%$, mp $40-$ $41.5^{\circ} \mathrm{C}$.

Anal. Calcd for $\mathrm{C}_{24} \mathrm{H}_{52} \mathrm{~N}_{2}: \mathrm{C}, 78.19 \% ; \mathrm{H}$, $14.22 \%$; N, 7.59\%. Found: C, 78.15\%; H, $14.20 \%$; N $7.30 \%$.

1,16-Dibromohexadecane was similarly converted to the dimethylamino derivative by reaction at $60^{\circ} \mathrm{C}$ for $43 \mathrm{~h}$ : colorless oil, yield $36 \%$. The NMR spectrum confirmed the conversion. 1,12-Dibromododecane was allowed 
to react with dimethylamine in ethanol at room temperature for one week. After solvent removal, the solid residue was neutralized with ethanolic $\mathrm{KOH}$ and extracted with benzene, and the oily residue was distilled: colorless oil, yield $50 \%$, bp $143-145^{\circ} \mathrm{C} / 0.2 \mathrm{mmHg}$.

Anal. Calcd for $\mathrm{C}_{16} \mathrm{H}_{36} \mathrm{~N}_{2}: \mathrm{C}, 74.92 \% ; \mathrm{H}$, $14.14 \%$; N, $10.92 \%$. Found: C, $74.56 \%$; H, $14.15 \%$; N, $10.56 \%$.

A similar procedure was used to convert 1,10-dibromodecane to the dimethylamino derivative: colorless oil, yield $30 \%$, bp $131-$ $134 \mathrm{C} / 1 \mathrm{mmHg}$.

Anal. Calcd for $\mathrm{C}_{14} \mathrm{H}_{32} \mathrm{~N}_{2}: \mathrm{C}, 76.11 \% ; \mathrm{H}$, $14.12 \%$; N, $12.26 \%$. Found: C, $73.11 \% ; \mathrm{H}$, $14.10 \%$; N, $12.01 \%$.

Hydroquinone $(10 \mathrm{~g}, \quad 0.09 \mathrm{~mol}, \quad$ Kishida Chemicals, reagent grade) in $200 \mathrm{ml}$ of ethanol, $10 \mathrm{~g}(0.18 \mathrm{~mol})$ of $\mathrm{KOH}$ in ethanol, and $150 \mathrm{~g}$ $(0.5 \mathrm{~mol})$ of distilled 1,10-dibromodecane were refluxed under $\mathrm{N}_{2}$ for $5 \mathrm{~h}$. The reaction mixture was poured into water and the precipitates were recrystallized repeatedly from ethyl

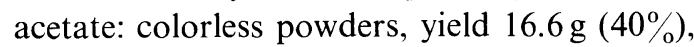
mp 75-78 $\mathrm{C}$.

Anal. Calcd for $\mathrm{C}_{26} \mathrm{H}_{44} \mathrm{O}_{2} \mathrm{Br}_{2} ; \mathrm{C}, 56.94 \% ; \mathrm{H}$, $8.09 \%$. Found: C, $58.99 \%$; H, $8.31 \%$.

1,4-Bis(10-bromodecyloxy)benzene $(5 \mathrm{~g}$ $9 \mathrm{mmol})$ in benzene was allowed to react with $32 \mathrm{~g}(0.18 \mathrm{~mol})$ of ethanolic dimethylamine in an ampoule at $80^{\circ} \mathrm{C}$ for $21 \mathrm{~h}$. After solvent removal, the colorless residue was treated with $\mathrm{KOH}$ and recrystallized from ethanol: colorless powders, yield $60 \%$ mp $59-62^{\circ} \mathrm{C}$. An NMR spectrum of the product (in $\mathrm{CDCl}_{3}$ ) was consistent with the bis-dimethylamino structure and thin layer chromatography indicated the absence of the starting material.

\section{Preparation of Amphiphiles}

In an ampoule were placed $3.5 \mathrm{~g}(0.009 \mathrm{~mol})$ of 1,20 -bis $(N, N$-dimethylamino)eicosane in $100 \mathrm{ml}$ of ethanol and $7.0 \mathrm{~g}(0.03 \mathrm{~mol})$ of distilled 1-bromodecane (bp $113-116^{\circ} \mathrm{C} / 12$ $\mathrm{mmHg}$ ) in ethanol. The sealed ampoule was immersed in an oil bath $\left(80^{\circ} \mathrm{C}\right)$ for $72 \mathrm{~h}$. A colorless solid was obtained upon solvent removal and recrystallized from acetone to give 1,20-bis ( $N, N$-dimethyldecylammonio) eicosane: yield, $87 \%$, mp $40 \rightarrow 155-165^{\circ} \mathrm{C}$ (the arrow indicates the liquid crystalline range).

Anal. Calcd for $\mathrm{C}_{44} \mathrm{H}_{94} \mathrm{~N}_{2} \mathrm{Br}_{2} \cdot \mathrm{H}_{2} \mathrm{O}$ : C, $63.74 \%$; H, $11.67 \%$; N, 3.38\%. Found: C, $64.14 \%$; H, $11.57 \%$ : N, 3.49\%.

The reaction of 1,20 -bis $(N, N$-dimethylamino)eicosane and 1-bromooctadecane was similarly conducted in an ampoule at $80^{\circ} \mathrm{C}$ for $90 \mathrm{~h}$. Colorless powders of 1,20-bis $(N, N$ dimethyloctadecylammonio)eicosane were obtained in $71 \%$ yield after recrystallization from acetone and acetone/ethanol: $\mathrm{mp} 50 \rightarrow$ $145 \rightarrow 170^{\circ} \mathrm{C}$.

Anal. Calcd for $\mathrm{C}_{60} \mathrm{H}_{126} \mathrm{~N}_{2} \mathrm{Br}_{2} \cdot \mathrm{H}_{2} \mathrm{O}: \mathrm{C}$, $68.41 \% ; \mathrm{H}, 12.25 \% ; \mathrm{N}, 2.66 \%$. Found: $\mathrm{C}$, $68.17 \%$; H, $11.99 \%$; N, $2.80 \%$.

NMR and IR spectra were consistent with the respective structures.

\section{Polymerization}

The following procedure was typical. Equimolar amounts $\left(2 \times 10^{-3} \mathrm{~mol}\right)$ of 1,20 dibromoeicosane and 1,20-bis $(N, N$-dimethylamino)eicosane were dissolved in $20 \mathrm{ml}$ of purified tetrahydrofuran (THF) and stirred magnetically at room temperature $\left(18-23^{\circ} \mathrm{C}\right)$ for $264 \mathrm{~h}$. The precipitates were centrifuged, washed with THF, and dried. The solid dissolved in warm dimethyl sulfoxide was added dropwise to THF with magnetic stirring. Stirring was continued for additional $5 \mathrm{~h}$. The polymer $(0.5 \mathrm{~g})$ was recovered by decantation and centrifugation. The other ionenes were prepared in a similar manner. The polymerization results are summarized in Table I.

\section{Measurement}

Electron microscopy was performed using a Hitachi H-500 instrument, as described elsewhere. ${ }^{15}$ Differential scanning calorimetry was carried out with a Daini-Seikosha SSC-560 instrument. Sample solutions were sealed in silver pans and the measurement was repeated 
from 0 to $80^{\circ} \mathrm{C}$ at a rate of $2^{\circ} \mathrm{C} / \mathrm{min}$. The details are described elsewhere. ${ }^{16}$ Molecular weights were determined by a small-angle light scattering apparatus with a He-Ne laser source (Toyo Soda, LS-8). ${ }^{17}$ The sample concentration was $5 \mathrm{mg} / 50 \mathrm{ml}\left(2.5 \times 10^{-4}-3.8 \times 10^{-4}\right.$ unit $\mathrm{M})$.

\section{RESULTS AND DISCUSSION}

\section{Polymerization}

The polymerizations were carried out at room temperature to assure predominance of the quaternization reaction.

$$
\begin{aligned}
& \left.\left.\mathrm{CH}_{3}-\mathrm{N}+\mathrm{CH}_{2}\right)_{{ }_{n}} \mathrm{~N}-\underset{\mathrm{CH}_{3}}{\mathrm{CH}_{3}}+\mathrm{Cr}+\mathrm{CH}_{2}\right)_{m} \mathrm{Br} \longrightarrow
\end{aligned}
$$

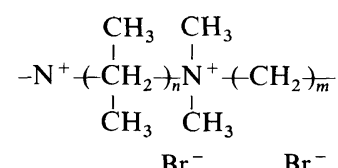

The products were powders or semi-solids. High polymers were not obtainable under the present conditions, and some of the low molecular-weight fractions may have been lost during reprecipitation. The complete removal of the starting materials (dibromides and diamines) from the polymers was ascertained by thin layer chromatography.

NMR spectra were consistent with the ionene structure. Figure 1 shows an NMR spectrum of $\mathrm{C}_{20}$ ionene. The major peak assignments are given in the insert. There are peaks apparently attributable to unreacted terminal units (peaks $\mathrm{c}$ and d), in addition to the peaks of monomer unit in polymer (peaks $a$ and $b$ ). The degree of polymerization (DP) (length of the ionene unit) can be estimated from the NMR peak ratio. Assuming the polymer chain end to consist of unreacted $\mathrm{BrCH}_{2}$ and/or $\left(\mathrm{CH}_{3}\right)_{2} \mathrm{NCH}_{2}$ groups, the relative amount of terminal and main-chain units in the $\mathrm{C}_{20}$ ionene are given by $1 / 2$ (area of peak c) $+1 / 8$ (area of peak d) and 1/36 (area of peak b), respectively. The degree of polymerization calculated from these data is given in

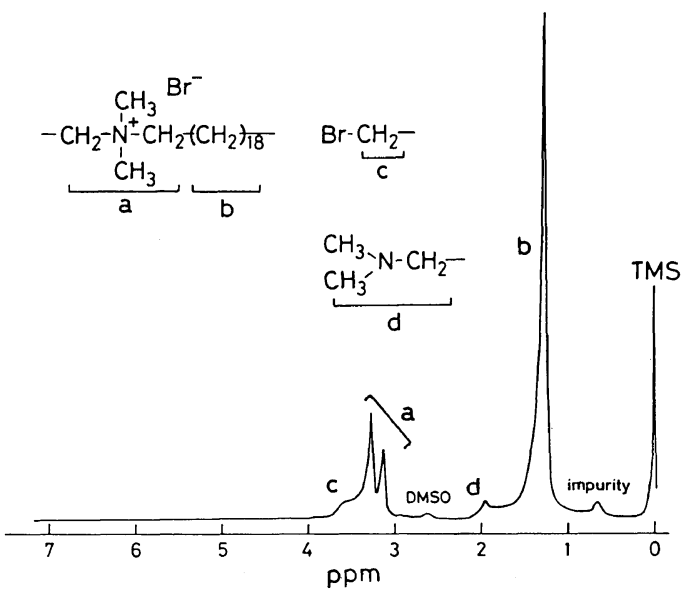

Figure 1. ${ }^{1} \mathrm{H}$ NMR spectrum of $\mathrm{C}_{20}$ ionene in $\mathrm{CDCl}_{3}$.

Table I. Polymerization ${ }^{\mathrm{a}}$

\begin{tabular}{|c|c|c|c|c|c|c|c|}
\hline \multirow{2}{*}{ Entry } & \multirow{2}{*}{ Polymer } & Total monomer concn & \multirow{2}{*}{ Solvent } & \multirow{2}{*}{$\frac{\text { Temp }}{\mathrm{C}}$} & \multirow{2}{*}{$\frac{\text { Time }}{h}$} & \multirow{2}{*}{$\frac{\text { Recovery }}{\%}$} & \multirow{2}{*}{$\overline{\mathrm{DP}}$} \\
\hline & & M & & & & & \\
\hline 1 & $\mathrm{C}_{20}$ ionene & 0.2 & THF & $18-23$ & 246 & 30 & $3-4$ \\
\hline 2 & $\mathrm{C}_{20}$ ionene & 0.6 & THF & ca. 18 & 100 & 58 & \\
\hline 3 & $\mathrm{C}_{16}$ ionene & 0.3 & $\mathrm{CHCl}_{3}$ & $26-32$ & 161 & 63 & $2.5-3.5$ \\
\hline 4 & $\mathrm{C}_{12}$ ionene & 0.2 & Benzene & ca. 25 & 286 & 17 & $2.2-3.2$ \\
\hline 5 & $\mathrm{C}_{10}$ ionene & 0.96 & Dry ethanol & ca. 22 & 216 & - & - \\
\hline 6 & $\mathrm{C}_{20} \mathrm{C}_{16}$ ionene & 0.2 & THF & $26-32$ & 173 & 72 & - \\
\hline 7 & $\mathrm{C}_{10} \mathrm{PhC}_{10}$ ionene & 0.2 & THF & ca. 27 & 144 & 45 & $4-5$ \\
\hline
\end{tabular}

a Anal. Calcd for $\mathrm{C}_{22} \mathrm{H}_{46} \mathrm{NBr} 0.5 \mathrm{H}_{2} \mathrm{O} ; \mathrm{C}, 63.90 \% ; \mathrm{H}, 11.46 \% ; \mathrm{N}, 3.39 \%$. Found (entry 1): $\mathrm{C}, 63.78 \% ; \mathrm{H}, 11.18 \% ; \mathrm{N}$, $3.21 \%$. Found (entry 2); C, $63.36 \% ; \mathrm{H}, 11.29 \% ; \mathrm{N}, 3.17 \%$. Calcd for $\mathrm{C}_{18} \mathrm{H}_{38} \mathrm{NBr} \mathrm{H}_{2} \mathrm{O}: \mathrm{C}, 59.00 \% ; \mathrm{H}, 11.00 \% ; \mathrm{N}$, $3.82 \%$. Found (entry 3): C, $59.43 \% ; \mathrm{H}, 10.76 \%$; N, 3.67\%. 
Table I. A similar estimation was made for other ionenes. DP was 3-4 for $\mathrm{C}_{20}$ ionene and smaller for $\mathrm{C}_{16}$ and $\mathrm{C}_{12}$ ionenes. Analogous values were found for ionenes containing the aromatic unit $\left(\mathrm{C}_{10} \mathrm{PhC}_{10}\right.$ ionene and $\mathrm{C}_{10}$ BphC $_{10}$ ionene. ${ }^{18}$ )<smiles>CC(C)(CCOc1ccc(-c2ccc(OCC[N+](C)(C)C(C)(C)C)cc2)cc1)C(Br)(Br)Br</smiles>

\section{Aggregation Behavior}

Table II summarizes the aggregation behavior of ionene oligomers and their analogs. Their molecular weights in water are very large. Since the molecular weights of the ionene oligomers are in the range of 600 to 2400 , the light scattering data indicate that approximately $10^{3}-10^{4}$ ionene molecules are aggregated in water. In the case of simple ionenes $\left(C_{n}\right.$ ionenes), the molecular weight increases with methylene chain length from $10^{5}$ to $10^{6} . \mathrm{C}_{20}$ ionene has a molecular weight close to those of typical bilayer membranes of dialkylammonium salts. It was noted previously that the molecular weight of bilayer aggregates of double-chain amphiphiles is one million or more. ${ }^{19}$
Vesicle formation was observed by electron microscopy for the aqueous aggregates of $\mathrm{C}_{18} \mathrm{~N}^{+} \mathrm{C}_{20} \mathrm{~N}^{+} \mathrm{C}_{18}$ and $\mathrm{C}_{20}$ ionene, as typically shown in Figure 2 (a and b). The thickness of the vesicle wall is $c a$. $100 \AA$ in both cases. This
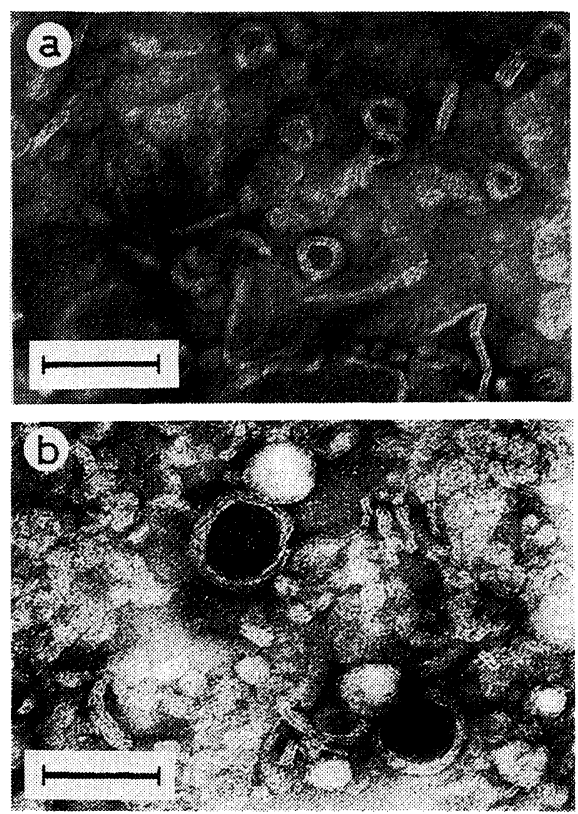

Figure 2. Electron micrographs, a; $\mathrm{C}_{18} \mathrm{~N}^{+} \mathrm{C}_{20} \mathrm{~N}^{+} \mathrm{C}_{18}$ $\mathrm{b} ; \mathrm{C}_{20}$ ionene. The sample solution $\left(5 \mathrm{mg} \mathrm{ml}^{-1}\right)$ was stained by uranyl acetate ( $\mathrm{pH} 4)$, Magnification $\times 24,000$. The bar represents $1000 \AA$.

Table II. Aggregation behavior

\begin{tabular}{|c|c|c|c|c|}
\hline \multirow{2}{*}{ Amphiphile } & \multirow{2}{*}{$\begin{array}{l}\text { Molecular weight } \\
\text { in water }\end{array}$} & \multirow{2}{*}{ Electron micrograph } & \multicolumn{2}{|c|}{ DSC } \\
\hline & & & Peak top $/{ }^{\circ} \mathrm{C}$ & $\Delta H / \mathrm{kcal} \mathrm{mol}^{-1}$ \\
\hline $\mathrm{C}_{18} \mathrm{~N}^{+} \mathrm{C}_{20} \mathrm{~N}^{+} \mathrm{C}_{18}$ & $(4-7) \times 10^{6}$ & Vesicle & 70 & $6.6(1.5 \mathrm{mM})^{\mathrm{b}}$ \\
\hline $\mathrm{C}_{10} \mathrm{~N}^{+} \mathrm{C}_{20} \mathrm{~N}^{+} \mathrm{C}_{10}$ & - & Not clear & None & \\
\hline $\mathrm{C}_{20}$ ionene & $2 \times 10^{6}$ & Vesicle & 53 & $7.3(80 \text { unit } \mathrm{mM})^{\mathrm{b}}$ \\
\hline $\mathrm{C}_{16}$ ionene & $1.2 \times 10^{5}$ & $(\text { Lamella })^{\mathrm{a}}$ & 26 & $4.7(60 \text { unit } \mathrm{mM})^{\mathrm{b}}$ \\
\hline $\mathrm{C}_{12}$ ionene & $(1-2) \times 10^{5}$ & Not clear & $\begin{array}{c}\text { Broad } \\
(40-50)\end{array}$ & \\
\hline $\mathrm{C}_{10}$ ionene & $(1-1.5) \times 10^{5}$ & Not clear & None & \\
\hline $\mathrm{C}_{20} \mathrm{C}_{16}$ ionene & -- & No structure & None & \\
\hline $\mathrm{C}_{10} \mathrm{PhC}_{10}$ ionene & $1.5 \times 10^{7}$ & $(\text { Disk-like })^{\mathrm{a}}$ & 63 & $1.8(60 \text { unit } \mathrm{mM})^{\mathrm{b}}$ \\
\hline $\mathrm{C}_{10} \mathrm{BphC}_{10}$ ionene $^{\mathrm{c}}$ & $1 \times 10^{8}$ & Disk-like & 62 & 0.8 \\
\hline
\end{tabular}

a Parenthesis indicates the morphology to be ill-defined.

b Figures in parenthesis are the sample concentrations for the DSC study.

c $\overline{\mathrm{DP}}=3-4$. 
value is much longer than the distance of the $\mathrm{C}_{20}$ chain between the two ammonium groups ( $45 \AA$ ). The observed wall may consist of double molecular layers. The structure (molecular membrane) formation is less apparent for $\mathrm{C}_{16}$ ionene, $\mathrm{C}_{12}$ ionene, $\mathrm{C}_{10}$ ionene, and $\mathrm{C}_{10} \mathrm{PhC}_{10}$ ionene. There are no indications of membrane formation in the case of $\mathrm{C}_{10} \mathrm{~N}^{+} \mathrm{C}_{20} \mathrm{~N}^{+} \mathrm{C}_{10}$ and $\mathrm{C}_{20} \mathrm{C}_{16}$ ionene. Disk-like structures were found in an electron micrograph of the aggregate of $\mathrm{C}_{10} \mathrm{BphC}_{10}$ ionene.

The crystal-to-liquid crystal phase transition is a fundamental property of the bilayer membrane, and has been observed for representative synthetic bilayers. ${ }^{16}$ Figure 3 displays a DSC chart for $\mathrm{C}_{20}$ ionene. The endothermic peak (peak top, $53^{\circ} \mathrm{C}$ ) is apparently attributed to the phase transition. The enthalpy change $(\Delta H)$ estimated from the peak area is $7.3 \mathrm{kcal}$ $\mathrm{mol}^{-1}$, in reasonable agreement with $\Delta H$ values for bilayers of typical double-chain ammonium amphiphiles. This value becomes smaller, however, on lowering the sample concentration. A sharp DSC peak was similarly found for $\mathrm{C}_{16}$ ionene, but $\mathrm{C}_{12}$ ionene gave a weak, broad peak at $40-50^{\circ} \mathrm{C}$ and $\mathrm{C}_{10}$ ionene did not show any peak. Aromatic ionenes $\left(\mathrm{C}_{10} \mathrm{PhC}_{10}\right.$ and $\left.\mathrm{C}_{10} \mathrm{BphC}_{10}\right)$ gave small peaks. $\mathrm{C}_{18} \mathrm{~N}^{+} \mathrm{C}_{20} \mathrm{~N}^{+} \mathrm{C}_{18}$ produced a distinct DSC

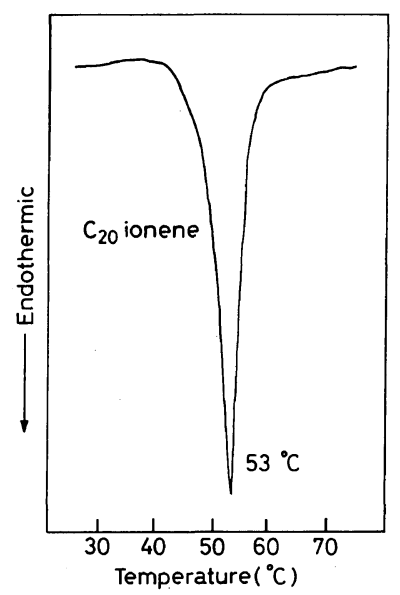

Figure 3. DSC thermogram of $\mathrm{C}_{20}$ ionene, heating rate $2.0^{\circ} \mathrm{C} / \mathrm{min}^{-1}$. The sample solution $(20 \mathrm{mM})$ was prepared by sonication. peak at $70^{\circ} \mathrm{C}$, but no peak was detected in the case of $\mathrm{C}_{10} \mathrm{~N}^{+} \mathrm{C}_{20} \mathrm{~N}^{+} \mathrm{C}_{10}$.

\section{Membrane Formation}

The aggregation behavior summarized in Table II suggests that molecular membranes are formed from several ionenes $\left(\mathrm{C}_{20}\right.$ ionene, $\mathrm{C}_{10} \mathrm{PhC}_{10}$ ionene and $\mathrm{C}_{10} \mathrm{BphC}_{10}$ ionene) and from $\mathrm{C}_{18} \mathrm{~N}^{+} \mathrm{C}_{20} \mathrm{~N}^{+} \mathrm{C}_{18}$. The latter compound may be regarded as that derived by connecting two double-chain ammonium amphiphiles at one of the alkyl tails. We showed previously that stable bilayers are produced from doublechain ammonium salts when the two alkyl tails are not shorter than $\mathrm{C}_{10} \cdot{ }^{10} \mathrm{C}_{18} \mathrm{~N}^{+} \mathrm{C}_{20} \mathrm{~N}^{+} \mathrm{C}_{18}$ corresponds to two molecules of $\mathrm{C}_{18} \mathrm{C}_{10} \mathrm{~N}^{+} 2 \mathrm{C}_{1}$ combined, and naturally belongs to a class of membrane-forming amphiphiles. $\mathrm{C}_{10} \mathrm{~N}^{+} \mathrm{C}_{20^{-}}$ $\mathrm{N}^{+} \mathrm{C}_{10}$ does not from stable membranes probably because the alkyl tail is too short.

$$
\begin{aligned}
& \mathrm{CH}_{3}\left(\mathrm{CH}_{2}\right)_{17} \\
& \mathrm{CH}_{3}\left(\mathrm{CH}_{2}\right)_{9}
\end{aligned}-\mathrm{N}^{+}-\mathrm{CH}_{3} \mathrm{CH}_{3} \mathrm{Br}^{-} \quad \mathrm{C}_{18} \mathrm{C}_{10} \mathrm{~N}^{+} 2 \mathrm{C}_{1}
$$

The same holds true for ionenes. $\mathrm{C}_{20}$ ionene gives stable molecular membranes, but not its lower homologs $\left(\mathrm{C}_{16}, \mathrm{C}_{12}\right.$, and $\mathrm{C}_{10}$ ionenes $)$, though $\mathrm{C}_{16}$ ionene may produce some ordered aggregates. When two hydrocarbon chains of different lengths are included $\left(\mathrm{C}_{20} \mathrm{C}_{16}\right.$ ionene), the ordered aggregate is not produced, as anticipated. The introduction of benzene or biphenyl unit into ionenes does not interfere with membrane formation. In fact, the incorporation of aromatic rigid segments into single-chain amphiphiles was found to promote bilayer formation. ${ }^{17}$

Schematic illustrations of membrane formation from ionenes and related amphiphiles are shown in Figure 4, and compared with those of ordinary ammonium bilayers. The representative molecular membranes contain; a, bilayers of double-chain amphiphiles; B, bilayers of single-chain amphiphiles; and C, monolayers of single-chain amphiphiles. It is readily apparent that the molecular membrane of a bis-ammonium amphiphile is produced 


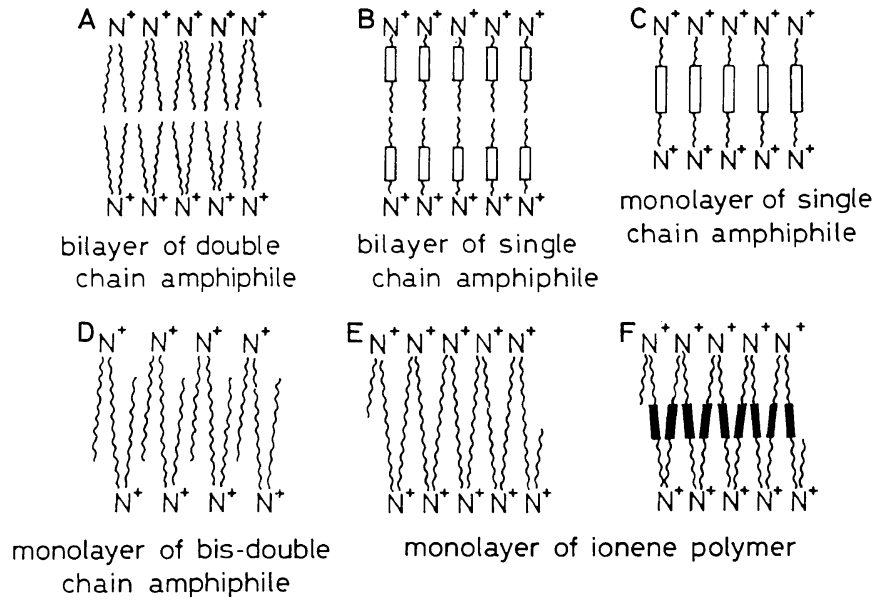

Figure 4. Schematic illustrations of the membrane formation from ionenes and related amphiphiles.

from bilayer A by connecting two doublechain component molecules at one end. When both of the alkyl chain ends are connected among different components of bilayer $\mathrm{A}$, ionene-type membranes result. The monolayer $F$ is obtainable from bilayer $B$ in a similar manner, and should possess the general structural characteristics in between those of membranes $\mathrm{B}$ and $\mathrm{C}$.

\section{CONCLUSIONS}

Our data show that stable molecular membranes are formed spontaneously from ionenetype amphiphiles. As described before, ${ }^{6.7}$ some vinyl copolymers undergo spontaneous assemblage to bilayer membranes. The present results are the second example of membraneforming polymeric (oligomeric) amphiphiles. The polymerization of pre-formed bilayer vesicles is being actively studied by many research groups; however, examples of bilayer formation by pre-formed polymers are relatively rare. It is expected in the future that molecular membranes will be obtainable from other types of polymers such as polyesters and polyamides.

Acknowledgement. The authors are grate- ful to Miss. R. Ando for her capable technical assistance and Mr. K. Aratake for preparation of some amphiphiles.

\section{REFERENCES}

1. T. Kunitake and Y. Okahata, J. Am. Chem. Soc., 99, 3860 (1977) and the subsequent papers.

2. For recent reviews see: J. H. Fendler "Membrane Mimetic Chemistry," Wiley-Interscience, New York, N.Y., 1982; J.-H. Fuhrhop and J. Mathieu, Angew. Chem. Int. Ed. Engl., 23, 100 (1984).

3. A. Akimoto, K. Dorn, L. Gros, H. Ringsdorf, and H. Schupp, Angew. Chem., 93, 108 (1981).

4. J.-H. Fendler and P. Tundo, Acc. Chem. Res., 17, 3 (1984).

5. S. L. Regen, P. Kirszenstejn, and A. Singh, Macromolecules, 16, 335 (1983); O. Albrecht and A. Laschewsky, ibid., 17, 1292 (1984); S. L. Regen, Z. Foltynowicz, and K. Yamaguchi, ibid., 17, 1293 (1984).

6. T. Kunitake, N. Nakashima, K. Takarabe, M. Nagai, A. Tsuge, and H. Yanagi, J. Am. Chem. Soc., 103, 5945 (1981).

7. T. Kunitake, M. Nagai, H. Yanagi, K. Takarabe, and N. Nakashima, J. Macromol. Sci.-Chem., A21, 1237 (1984).

8. N. Noguchi and A. Rembaum, J. Polym. Sci., B, 7, 383 (1969) and their subsequent papers.

9. E. Tsuchida, K. Sanada, and K. Moribe, Makromol. Chem., 152, 207 (1972); ibid., 155, 35 (1972).

10. T. Kunitake, Y. Okahata, K. Tamaki, M. Takayanagi, and F. Kumamaru, Chem. Lett., 387 (1977).

11. Y. Okahata and T. Kunitake, J. Am. Chem. Soc., 
101, 5231 (1981).

12. E. C. Hornig, "Organic Synthesis," Coll. Vol. 3, 1955, p 227.

13. F. L. M. Pattison, W. C. Howell, A. J. McNamara, J. C. Schneider, and H. F. Walker, J. Org. Chem., 21, 736 (1956).

14. P. Chuit and T. Hausser, Helv. Chem. Acta, 12, 856 (1929).

15. T. Kunitake and Y. Okahata, J. Am. Chem. Soc., 102, 549 (1980).
16. Y. Okahata, R. Ando, and T. Kunitake, Ber. Bunsenges. Phys. Chem., 85, 789 (1981).

17. T. Kunitake, Y. Okahata, M. Shimomura, S. Yasunami, and K. Takarabe, J. Am. Chem. Soc., 103, 5401 (1981).

18. A Tsuge, the preparation of $\mathrm{C}_{10} \mathrm{BphC}_{10}$ ionene will be discussed elsewhere.

19. Y. Okahata, R. Ando, and T. Kunitake, Bull. Chem. Soc. Jpn., 52, 3647 (1979). 